\title{
ANALISIS DISKRIMINAN FISHER UNTUK HUBUNGAN INCIDENCE RATE DENGAN INDEKS ENTOMOLOGI BERDASARKAN KLASIFIKASI EKOSISTEM
}

\section{Fisher's Discriminant Analysis in the Relationship of Incidence Rate and Entomology Index Based on Classification of Ecosystems}

\author{
Revi Rosavika Kinansi, Mega Tyas Prihatin \\ Balai Besar Penelitian dan Pengembangan Vektor dan Reservoir Penyakit - Badan Litbang Kesehatan \\ Naskah masuk: 26 Agustus 2019 Perbaikan: 26 September 2019 Layak terbit: 20 November 2019 \\ https://doi.org/10.22435/hsr.v22i4.2151
}

\begin{abstract}
ABSTRAK
Analisis diskriminan adalah salah satu teknik statistik yang dapat digunakan untuk memberikan pendugaan yang paling tepat untuk mengklasifikasikan individu ke dalam salah satu kelompok berdasarkan skor variabel bebas (skor diskriminan). Terdapat 2 asumsi utama dalam melakukan analisis diskriminan, yaitu normalitas data harus terpenuhi dan kesamaan varian-kovarian. Penelitian ini bertujuan untuk mengetahui apakah terdapat hubungan antara Incidence Rate (IR) DBD dengan indeks entomologi jika suatu wilayah diklasifikasi menjadi pantai-bukan pantai dan perdesaan-perkotaan. Penelitian telah dilakukan di 78 kabupaten di Indonesia pada Riset Khusus Vektor dan Reservoir Penyakit tahun 2016 hingga 2017. Wilayah geografis Indonesia yang beriklim tropis dengan tiga bulan musim hujan pada Desember, Januari, Februari dan tiga bulan musim kemarau pada Juni, Juli, Agustus dapat menjadi wilayah hiperendemik DBD. Kondisi tersebut diperparah oleh perkembangan wilayah perkotaan yang semakin kompleks dan perkembangan wilayah pedesaan menjadi kota yang menurunkan kualitas lingkungan hidup dan berdampak pada perluasan habitat nyamuk Aedes aegypti vektor penyakit DBD. Data yang akan dianalisis adalah data indeks entomologi berupa angka $\mathrm{HI}, \mathrm{BI}, \mathrm{Cl}$ dan $\mathrm{ABJ}$ terhadap IR. Hasil analisis memberikan informasi bahwa nilai Canonical Correlation yang sangat rendah yaitu 0,076, jika diklasifikasi menjadi pantai dan bukan pantai menunjukkan tidak terdapat hubungan antara variabel bebas dengan variabel terikat. Nilai Canonical Correlation yang cukup tinggi yaitu 0,219, jika diklasifikasi menjadi perdesaan dan perkotaan menunjukkan terdapat hubungan antara variabel bebas dengan variabel terikat nya. Berdasarkan hasil penelitian ini, ekosistem padat penduduk di perkotaan atau perdesaan memiliki peluang besar terhadap adanya kasus demam berdarah dengue, sehingga masyarakat perlu melakukan monitoring terhadap jentik nyamuk untuk pengendalian DBD.
\end{abstract}

Kata kunci: analisis diskriminan Fisher, klasifikasi wilayah, normalitas data, kesamaan varian-kovarian, Demam Berdarah Dengue, indeks entomologi, incidence rate

\begin{abstract}
Discriminant analysis is one of the statistical techniques that may use to provide the most appropriate estimation for classifying individuals into one group based on the independent variable score (discriminant score). There are 2 main assumptions in discriminant analysis such as fulfilled data normality and similarity of variant-covariants. This study aims to determine whether there is a relationship between DHF Incidence Rate (IR) and entomology index if a region is classified as a coast-not a coast and rural-urban. This research conducted in 78 districts in Indonesia carried out in Disease Reservoir and Vector Specific Research from 2016 to 2017. The geographical area of Indonesia which has a tropical climate with three months of rainy season in December, January, February and three months of the dry season in June, July, August can be a hyperendemic area of DHF. This condition is exacerbated by the development of increasingly complex urban areas and the development of rural areas into cities that reduce environmental quality and have an impact on the expansion of the habitat of Aedes aegypti as vector of DHF. The data to be analyzed are the entomology index in
\end{abstract}

Korespondensi:

Revi Rosavika Kinansi

Balai Besar Penelitian dan Pengembangan Vektor

E-mail: revi_rosavika@yahoo.com 
the form of numbers of $\mathrm{HI}, \mathrm{BI}, \mathrm{Cl}$ and $\mathrm{ABJ}$ against IR. The results of the analysis provide information that the very low value of Canonical Correlation is 0.076 classified as coast and not coast so that there is no relationship between the independent variable and the dependent variable. While the Canonical Correlation value is quite high, which is 0.219 classified as rural and urban showed that there is a relationship between the independent variable and the dependent variable. Based on the results, densely populated ecosystems in urban or rural areas have a great chance of cases of dengue hemorrhagic fever, so people need to monitor mosquito larvae to control DHF.

Keywords: Fisher's discriminant analysis, regional classification, data normality, variance-covariance similarity, Dengue Hemorrhagic Fever, entomological index, incidence rate

\section{PENDAHULUAN}

Menurut Johnson dan Wichern (Johnson \& Wichern, 2007), analisis diskriminan digunakan untuk mengklasifikasikan individu ke dalam salah satu dari dua kelompok atau lebih. Fungsi diskriminan yang dihasilkan dapat digunakan untuk memberikan pendugaan yang paling tepat untuk mengklasifikasikan individu ke dalam salah satu kelompok berdasarkan skor variabel bebas (skor diskriminan) (Johnson \& Wichern, 2007). Analisis diskriminan adalah salah satu teknik statistik yang bisa digunakan pada hubungan dependensi (hubungan antar variabel dimana sudah bisa dibedakan mana variabel terikat dan mana variabel bebas). Lebih spesifik lagi, analisis diskriminan digunakan pada kasus dimana variabel terikat berupa data kualitatif dan variabel bebas berupa data kuantitatif. Analisis diskriminan bertujuan untuk mengklasifikasikan suatu individu atau observasi ke dalam kelompok yang saling bebas (mutually exclusive/ disjoint) dan menyeluruh (exhaustive) berdasarkan sejumlah variabel bebas (Rosy, 2018).

Ada dua asumsi utama yang harus dipenuhi pada analisis diskriminan ini, yaitu: 1.Sejumlah $p$ variabel bebas harus berdistribusi normal, 2.Matriks varians-covarians variabel bebas berukuran $p \times p$ pada kedua kelompok harus sama. Jika dianalogikan dengan regresi linier, maka analisis diskriminan merupakan kebalikannya. Pada regresi linier, variabel terikat yang harus mengikuti distribusi normal dan homoskedastisitas, sedangkan variabel bebas diasumsikan fixed, artinya variabel bebas tidak disyaratkan mengikuti sebaran tertentu. Untuk analisis diskriminan, variabel bebasnya seperti sudah disebutkan di atas harus mengikuti distribusi normal dan homoskedastisitas, sedangkan variabel terikatnya fixed (Rosy, 2018). Terdapat 2 metode klasifikasi individu yaitu analisis diskriminan dan metode Naïve Bayes, berdasarkan penelitian yang pernah dilakukan Rofiq, dkk (Rofiq et al., 2016), analisis diskriminan memberikan keakuratan hasil analisis sebesar $90 \%$, sedangkan metode Naïve Bayes memberikan hasil
$83,33 \%$. Analisis diskriminan digunakan pada kasus dimana variabel bebas berupa data metrik (interval atau rasio) dan variabel terikat berupa data nonmetrik (nominal atau ordinal). Model analisis diskriminan berkenaan dengan kombinasi linear memiliki bentuk sebagai berikut:

$\left.Y_{j i}=b^{\top} X_{j i g}=b_{1} X_{j i 1}+b_{2} X_{j i 2}+\ldots+b_{g} X_{j k g} \ldots \ldots \ldots \ldots \ldots \ldots \ldots . . .1\right)$

Dengan $g=1,2, \ldots, p, j=1,2, \ldots, n i$, dan $i=1,2, \ldots, k$

Klasifikasi mempunyai tujuan untuk memasukkan observasi baru ke dalam kelompok yang telah mempunyai label kelompok. Berdasarkan Johnson and Wichern (2007)(Johnson \& Wichern, 2007), Aturan klasifikasi berdasarkan dua kelompok (populasi) normal dengan matriks kovariansi yang sama dijelaskan sebagai berikut:

$Z_{C U}=\frac{n_{1} Z_{1}+n_{2} Z_{2}}{n 1+n 2}$

di mana:

Zcu = angka kritis, yang berfungsi sebagai cut off score.

$\mathrm{n}_{1}=$ besar sampel di grup $1, \mathrm{n}_{2}=$ besar sampel di grup $2, z_{1}=$ angka centroid pada grup $1 . z_{2}=$ angka centroid pada grup 2. Dalam mengetahui hubungan antara variabel terikat dengan variabel bebas pada analisis diskriminan, digunakan angka korelasi kanonik. Korelasi kanonik berfungsi menguraikan struktur hubungan di dalam kelompok variabel terikat maupun dalam kelompok variabel bebas (Prabawa et al., 2017). Nilai korelasi kanonik memiliki rentang nilai dari 0 hingga 1 . Semakin nilai korelasi kanonik mendekati 1 , maka fungsi diskriminan yang terbentuk semakin baik.

Studi kasus dalam penelitian ini yang akan diketahui hubungannya adalah hasil Riset Khusus Vektor dan Reservoir Penyakit tahun 2016-2017 di 78 Kabupaten di Indonesia yang disurvei berdasarkan ekosistem dekat pemukiman. Ekosistem dekat pemukiman dibagi menjadi wilayah perdesaan, 
perkotaan, pantai dekat pemukiman (PDP) dan non pantai dekat pemukiman (NHDP). Peningkatan jumlah kasus serta bertambahnya wilayah yang terjangkit DBD, karena semakin baiknya sarana transportasi penduduk dan adanya pemukiman baru (Astuti et al., 2016). Berdasarkan laporan Kementerian Kesehatan RI tahun 2015, angka kesakitan (IR) DBD di Indonesia tahun 2011-2015 meningkat. Angka kesakitan atau Incidence Rate (IR) di 34 provinsi di 2015 mencapai 50.75 per 100 ribu penduduk, dan IR di 2016 mencapai 78.85 per 100 ribu penduduk. Angka ini masih lebih tinggi dari target IR nasional yaitu 49 per 100 ribu penduduk. Berdasarkan data Dirjen Pencegahan dan Pengendalian Penyakit (P2P) Kementerian Kesehatan RI pada tahun 2017, dengan jumlah penduduk sebesar 261.890.872, jumlah kasus DBD di Indonesia mencapai 59.047 kasus dengan IR (Incident Rate) 22,55 per 100 ribu penduduk dan 444 penduduk meninggal karena DBD. Terhitung sejak Januari hingga Mei 2017 tercatat sebanyak 17.877 kasus, dengan 115 kematian (Kementerian Kesehatan RI., 2017).

Demam Berdarah Dengue (DBD) yang disebabkan oleh virus dengue ditularkan melalui gigitan nyamuk Aedes aegypti (Khin and Than, 2003). Wilayah geografis Indonesia yang beriklim tropis dengan suhu yang berkisar $26,0-29,0^{\circ} \mathrm{C}$ dengan tiga bulan musim hujan pada Desember, Januari, Februari dan tiga bulan musim kemarau pada Juni, Juli, Agustus dapat menjadi wilayah hiperendemik DBD. Kondisi tersebut diperparah oleh perkembangan wilayah perkotaan yang semakin kompleks dan perkembangan wilayah pedesaan menjadi kota yang menurunkan kualitas lingkungan hidup dan berdampak pada perluasan habitat nyamuk Ae. aegypti vektor penyakit DBD (Fidayanto et al., 2013). Ekosistem pantai dan wilayah perkotaan ideal bagi perkembangbiakan nyamuk $A$ e. aegypti karena mempunyai rata-rata suhu $27,85^{\circ} \mathrm{C}$ dengan rata-rata kelembaban $75,75 \%$. Antara suhu dan kelembaban saling memengaruhi untuk perkembangbiakan Ae. aegypti. Dengan demikian, kondisi iklim (suhu dan kelembaban) ini akan mendukung peningkatan kepadatan populasi nyamuk tersebut, selanjutnya berdampak pada penularan dan penyebaran penyakit DBD. Suhu $20-30^{\circ} \mathrm{C}$ dengan kelembaban pada kisaran $60-90 \%$, merupakan kondisi optimum untuk tumbuh kembang nyamuk Ae. Aegypti (Craven et al., 2008). Faktor iklim, perubahan ekologi dan faktor sosial demografi memegang peranan penting dalam peningkatan dan perluasan daerah endemis penyakit
DBD (Khairunisa Ummi; Nur Endah Wahyuningsih dan Hapsari, 2017). Penularan DBD dipengaruhi oleh unsur iklim. Suhu mempengaruhi reproduksi nyamuk, angka gigitan, masa inkubasi ekstrinstik virus, dan pergesaran daerah distribusi nyamuk (Promprou, 2005). Spesies nyamuk Aedes sp. hidup sangat baik dalam wadah buatan manusia di pemukiman perkotaan, pinggiran kota dan pedesaan di daerah tropis dan subtropis (Passos et al., 2003), (Juliano et al., 2004), (Honório et al., 2006). (Dini et al., 2010) dan (Pham et al., 2011) menjelaskan bahwa faktor iklim seperti suhu, curah hujan dan kelembaban serta penyinaran matahari sangat berpengaruh terhadap kejadian DBD di dataran tinggi Vietnam. Kenaikan suhu berpengaruh pada menyebaran penyakit dengue di Thailand (Focks et al., 2007), (Nakhapakorn \& N.K. Tripathi, 2005) dan Indonesia (Lei et al., 2001) serta di Singapura (Burattini et al., 2007).

Faktor lingkungan yang menyebabkan peningkatan insiden DBD antara lain karena sanitasi yang buruk (Centers for Disease Control and Prevention, 2012), keberadaan jentik pada Tempat Penampungan Air (TPA), mobilitas penduduk serta kepadatan penduduk. Kebiasaan masyarakat yang merugikan kesehatan dan kurang memperhatikan kebersihan lingkungan akan meningkatkan risiko terjadinya transmisi DBD. Kebiasaan ini akan menjadi lebih buruk di mana masyarakat sulit mendapatkan air bersih, sehingga mereka cenderung untuk menyimpan air dalam tandon bak air, karena TPA tersebut sering tidak dicuci dan dibersihkan secara rutin pada akhirnya menjadi potensial sebagai tempat perindukan nyamuk Ae. Aegypti (Sulistyorini Evi et al., 2016). Data surveilans kepadatan nyamuk Ae. aegypti dapat diukur menggunakan indikator entomologi yaitu Container Index $(\mathrm{Cl})$, House Index (HI), dan Breteau Index $(\mathrm{BI})$. House index $(\mathrm{HI})$, Container Index $(\mathrm{Cl})$, Breteau Index (BI) dan Angka Bebas Jentik (ABJ) merupakan parameter entomologi yang mempunyai relevansi langsung dengan dinamika penularan penyakit. House Index $(\mathrm{HI})$ dihitung dengan membagi jumlah rumah yang terdapat larva nyamuk dibagi dengan jumlah rumah yang diperiksa dikalikan $100 \%$. Container Index $(\mathrm{Cl})$ dihitung dengan membagi jumlah tempat penampungan air yang terdapat larva dan atau pupa nyamuk dengan jumlah yang diperiksa dikalikan seratus persen. Breateau Index (BI) dihitung dengan membagi jumlah tempat penampungan air yang terdapat jentik atau pupa nyamuk dengan jumlah rumah yang diperiksa dikalikan $100 \%$ (Mulyati et al., 2017). 
Tabel 1. Hasil Uji Normalitas Data Kolmogorov-Smirnov Variabel Indeks Entomologi (CI, BI, ABJ, IR dan HI)

\begin{tabular}{llccccc}
\hline & & CI & BI & ABJ & IR & HI \\
\hline Besar Sampel & & 78 & 78 & 78 & 78 & 78 \\
Normal Parameters & Rerata & 3,9766 & 6,5910 & 7,4440 & 7,4251 & 6,2428 \\
& Std. Deviasi & 1,72228 & 3,49683 & 1,50658 & 8,89748 & 1,51581 \\
Kolmogorov-Smirnov Z & & 1,397 &, 939 & 1,105 & 1,784 &, 608 \\
Asymp. Sig. (2-tailed) & &, 040 &, 342 &, 174 &, 003 &, 853 \\
\hline
\end{tabular}

Tujuan yang ingin dicapai dalam penelitian ini adalah mengetahui apakah terdapat hubungan Incidence Rate (IR) kejadian Demam Berdarah Dengue (DBD) dengan ekosistem pantai-bukan pantai dan perdesaan-perkotaan menggunakan analisis diskriminan Fisher's di 78 Kabupaten di Indonesia selama tahun 2016 hingga 2017. Klasifikasi ekosistem pantai-bukan pantai dan perdesaan-perkotaan merupakan variabel terikat yang diberi kode 1 dan 2 , yang mendasari dilakukan analisis diskriminan Fisher.

\section{Metode}

Penelitian ini menggunakan raw data Riset Khusus Vektor dan Reservoir Penyakit tahun 2016 dan 2017. Data adalah milik Badan Penelitian dan Pengembangan Kesehatan. Jenis penelitian ini adalah observasional. Pada Riset khusus vektor dan reservoir penyakit, khususnya untuk survei jentik dilakukan di ekosistem dekat pemukiman yaitu pantai dekat pemukiman (PDP), hutan dekat pemukiman (HDP), dan non hutan dekat pemukiman (NHDP). Penelitian ini dilakukan di 78 kabupaten di Indonesia, dengan mengelompokkan menjadi pantai-bukan pantai dan perdesaan-perkotaan. PDP termasuk daerah pantai, HDP termasuk daerah non pantai, dan NHDP adalah daerah perdesaan dan perkotaan.

Analisis menggunakan diskriminan Fisher's. Langkah pertama harus melakukan uji asumsi analisis Diskriman Fisher's. Asumsi yang harus dipenuhi yaitu variabel bebas berdistribusi normal dan matriks varian-kovarian variabel bebas pada kedua kelompok harus sama.

Data yang dianalisis meliputi perhitungan kepadatan jentik nyamuk sebagai variabel bebas, dilakukan menggunakan indikator entomologi berupa House Index (HI), Container Index (Cl) dan Breateu Index (BI) serta Angka Bebas Jentik (ABJ). Variabel terikat berupa angka Incidence Rate (IR) di 78 Kabupaten endemis Demam Berdarah Dengue. Variabel terikat dan variabel bebas dikelompokkan menjadi pantai-bukan pantai dan perdesaan-perkotaan. Analisis data menggunakan analisis diskriminan Fisher's menggunakan perangkat lunak SPSS seri 17 versi 4.0 .

\section{Hasil}

Sebelum melakukan analisis diskriminan, dilakukan pengujian distribusi normal univariat Kolmogorov-Smirnov dan uji kesamaan varian-kovarian Box's $M$ terhadap semua variabel baik variabel terikat dan variabel bebas (Rofiq et al., 2016). Ada banyak metode uji normalitas data di dalam menentukan apakah data berdistribusi normal atau tidak. Beberapa metode uji memiliki kelebihan masing-masing seperti yang disampaikan oleh Dahlan (Dahlan, 2009) menyebutkan bahwa uji Kolmogorov-Smirnov lebih tepat untuk sampel yang lebih dari 50 (Johnson \& Wichern, 2007). Berdasarkan analisis uji normalitas masing-masing variabel terikat dan variabel bebas, didapatkan hasil sebagai berikut pada tabel 1

Berdasarkan Tabel 1, jika nilai $p$-value (Asymp. Sig 2-tailed) Kolmogorov-Smirnov di atas 0,05 maka distribusi data dinyatakan memenuhi asumsi normalitas, dan jika nilainya di bawah 0,05 maka distribusi data tidak normal. Dari hasil di atas, diketahui data $\mathrm{Cl}$ dan IR tersebar tidak normal. Berdasarkan panduan transformasi data oleh Yap dan

Tabel 2. Transformasi Data Berdasarkan Bentuk Grafik Histogram

\begin{tabular}{lc}
\hline \multicolumn{1}{c}{ Bentuk Grafik Histogram } & $\begin{array}{c}\text { Bentuk Transformasi } \\
\text { Data }\end{array}$ \\
\hline Moderate positive skewness & SQRT(x) \\
Substansial positive skewness & LG10(x) \\
Severe positive skewness & $1 / \mathrm{x}$ \\
Moderate negative skewness & SQRT(k-x) \\
Substansial negative skewness & LG10(k-x) \\
Severe negative skewness & $1 /(k-x)$ \\
\hline
\end{tabular}

Dengan $\mathrm{k}=$ nilai tertinggi dari raw data 
Tabel 3. Hasil Uji Normalitas Data Kolmogorov-Smirnov Variabel $\mathrm{Cl}$ dan IR

\begin{tabular}{llcl}
\hline & & Cl & IR \\
\hline Besar Sampel & & 78 & 78 \\
Normal Parameters & Rerata & 2,79167 & 4,04278 \\
& Std. Deviasi &, 805871 & 1,744616 \\
Kolmogorov-Smirnov Z & 1,695 &, 580 \\
Asymp. Sig. (2-tailed) &, 006 &, 889 \\
\hline
\end{tabular}

$\mathrm{Cl}$

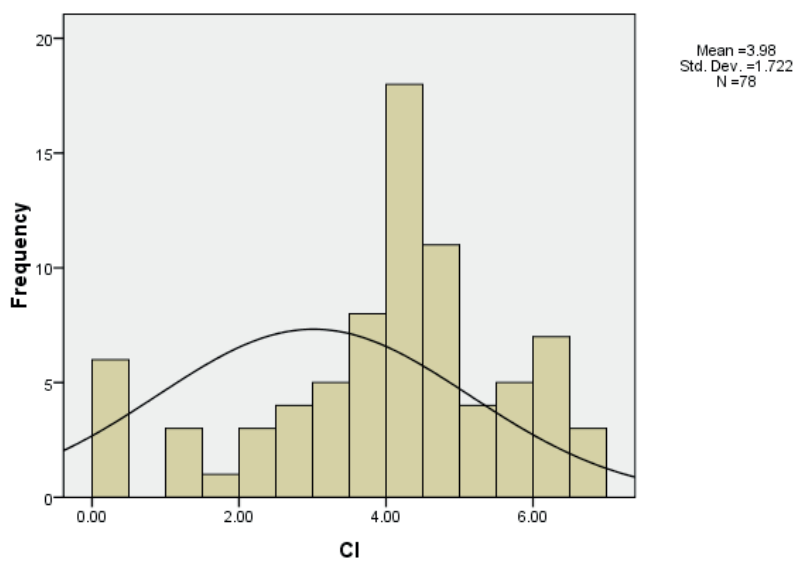

Gambar 1. Grafik Sebaran data variabel $\mathrm{Cl}$

Sim (Yap \& Sim, 2011), beberapa cara transformasi data adalah sebagai berikut pada Tabel 2 .

Variabel $\mathrm{Cl}$ dan IR dianalisis tersendiri, kemudian ditransformasi menggunakan Log- $\mathrm{N}$ dan hasilnya seperti di tabel 3.

Berdasarkan Tabel 3, dapat dilihat bahwa variabel IR sudah berdistribusi normal, namun $\mathrm{Cl}$ belum berdistribusi normal. Variabel $\mathrm{Cl}$ dibuat grafik histogram untuk mengetahui distribusi sebarannya. Grafik sebaran variabel $\mathrm{Cl}$ berada pada gambar 1 .

Berdasarkan arah sebaran data, variabel $\mathrm{Cl}$ lebih condong $\mathrm{Cl}$ ke kanan, maka variabel $\mathrm{Cl}$ ditransformasi menggunakan sqrt (nilai Max-x) karena Moderate

Tabel 4. Hasil Uji Normalitas Data Kolmogorov-Smirnov Variabel $\mathrm{Cl}$

\begin{tabular}{lll}
\hline & & Cl \\
\hline Besar Sampel & & 78 \\
Normal Parameters & Rerata & 5,07062 \\
& Std. Deviasi & 1,389921 \\
Kolmogorov-Smirnov Z & & 1,259 \\
Asymp. Sig. (2-tailed) &, 084 \\
\hline
\end{tabular}

Tabel 5. Hasil Uji Kesamaan Varian-Kovarian Variabel

\begin{tabular}{llc}
\hline Box's M & & 3,437 \\
& Approx. & 3,391 \\
F & df1 & 1 \\
& df2 & 16541,718 \\
& Sig. &, 066 \\
\hline
\end{tabular}

Tabel 6. Hasil Uji Diskriminan Fisher Klasifikasi PantaiBukan Pantai

Eigenvalues

\begin{tabular}{lcccc}
\hline $\begin{array}{c}\text { Func Eigen } \\
\text { tion } \\
\text { value Variance }\end{array}$ & $\begin{array}{c}\text { Cumulative } \\
\%\end{array}$ & $\begin{array}{c}\text { Canonical } \\
\text { Correlation }\end{array}$ & $\begin{array}{c}\text { p-va } \\
\text { lue }\end{array}$ \\
\hline $\begin{array}{l}\text { Pantai- } \\
\text { Non }, 006 \text { a }\end{array}$ & 100,0 & 100,0 &, 076 & 0,066 \\
Pantai & & & & \\
\hline
\end{tabular}

negative skewness, berikut hasil hasil uji normalitas nya:

Berdasarkan uji kolmogorov smirnov, nilai Asymp. Sig 2-Tailed lebih dari 0,05, sehingga variabel $\mathrm{Cl}$ sudah berdistribusi normal menggunakan data hasil transformasi. Selanjutnya dilakukan pengujian kesamaan varian-kovarian semua variabel menggunakan uji Box's M menggunakan SPSS, dengan hasil di tabel 5 .

Berdasarkan nilai $p$-value statistik uji Box' M diketahui nilai $p$-value 0,066 $(>0,05)$ maka disimpulkan bahwa varian/ragam kedua kelompok data sama/homogen. Berdasarkan asumsi yang harus dipenuhi untuk melakukan analisis diskriminan Fisher, sudah memenuhi distribusi normal multivariat Kolmogorov-Smirnov dan uji kesamaan varians-kovarian Box's $M$. Untuk selanjutnya dilakukan analisis diskriminan Fisher klasifikasi pantai-bukan pantai dan perdesaan-perkotaan. Berdasarkan analisis diskriminan Fisher untuk klasifikasi pantai-bukan pantai, diperoleh hasil yang terdapat di tabel 6.

Pada tabel Eigenvalues terdapat nilai canonical correlation. Nilai canonical correlation digunakan untuk mengukur derajat hubungan antara hasil diskriminan atau besarnya variabilitas yang mampu diterangkan oleh variabel terikat terhadap variabel bebas (Oktaviani \& Notobroto, 2014). Dari Tabel 6, diperoleh nilai canonical correlation sebesar 0,076 bila dikuadratkan $(0,076 \times 0,076)=0.0058$, artinya hanya $0,58 \%$ ragam dari variabel independen (IR) dapat dijelaskan dari model diskriminan yang terbentuk. Nilai korelasi kanonikal menunjukkan 
Tabel 7. Model Diskriminan Fishers

\section{Stratifikasi}

\begin{tabular}{ccc}
\hline & Bukan Pantai & Pantai \\
\hline $\mathrm{HI}$ & 2,638 & 2,641 \\
$\mathrm{Cl}$ &,- 217 &,- 233 \\
$\mathrm{BI}$ &, 004 &, 018 \\
$\mathrm{ABJ}$ & 2,515 & 2,547 \\
Konstanta & $-125,193$ & $-127,585$ \\
\hline
\end{tabular}

Tabel 8. Tabel Wilk's Lambda Klasifikasi Pantai-Non Pantai

\section{Wilks' Lambda}

\begin{tabular}{cccc}
\hline $\begin{array}{c}\text { Wilks' } \\
\text { Lambda }\end{array}$ & Chi-square & $\begin{array}{c}\text { n-1 } \\
\text { prediktor }\end{array}$ & p-value \\
\hline, 942 & 4,419 & 4 &, 352 \\
\hline
\end{tabular}

hubungan antara nilai diskriminan dengan kelompok. Nilai sebesar 0,076 berarti hubungan antara variabel pantai-non pantai dengan IR sangat rendah karena menjauhi angka 1 (besarnya korelasi antara 0-1).

Berdasarkan Tabel 7, model yang terbentuk untuk stratifikasi ekosistem pantai dan bukan pantai adalah sebagai berikut:

Bukan Pantai $\rightarrow Y=-125,193+2,638 \mathrm{HI}-0,217 \mathrm{Cl}+0$, $004 \mathrm{BI}+2,515 \mathrm{ABJ}$

Pantai $\rightarrow \mathrm{Y}=-127,585+2,641 \mathrm{HI}-0,233 \mathrm{Cl}+0,018 \mathrm{BI}+2$, $547 \mathrm{ABJ}$

Berdasarkan Uji Wilk's Lambda, kedua model tidak memiliki perbedaan yang signifikan, jika dilihat dari konstanta prediktor dan $p$-value, hal ini berarti, dengan distratifikasi, tidak ada hubungannya antara indeks entomologi dengan Incidence Rate. Tahap selanjutnya adalah melakukan analisis diskriminan untuk klasifikasi perdesaan-perkotaan. Hasil analisis terdapat di tabel 8.

Berdasarkan Tabel 9, diperoleh nilai canonical correlation sebesar 0,219 bila di kuadratkan $(0,219$ $\mathrm{x} 0,219)=0,046$, artinya hanya $4,8 \%$ varians dari

Tabel 9. Hasil Uji Diskriminan Fisher Klasifikasi Perdesaanperkotaan

Eigenvalues

\begin{tabular}{cccccc}
\hline $\begin{array}{c}\text { Func } \\
\text { tion }\end{array}$ & $\begin{array}{c}\text { Eigen } \\
\text { value }\end{array}$ & $\begin{array}{c}\% \text { of } \\
\text { Variance }\end{array}$ & $\begin{array}{c}\text { Cumulative } \\
\%\end{array}$ & $\begin{array}{c}\text { Canonical } \\
\text { Correlation }\end{array}$ & $\begin{array}{c}\text { p-va } \\
\text { lue }\end{array}$ \\
\hline $\begin{array}{c}\text { Desa- } \\
\text { Kota }\end{array}$ &, 051 & 100,0 & 100,0 &, 219 & 0,05 \\
\hline
\end{tabular}

Tabel 10. Model Diskriminan Fisher's Klasifikasi Perdesaan-Perkotaan

\begin{tabular}{lcc}
\hline & \multicolumn{2}{c}{ 1=DESA,2=KOTA } \\
\hline $\mathrm{HI}$ & $\mathbf{1 . 0 0}$ & $\mathbf{2 . 0 0}$ \\
$\mathrm{CI}$ & 2.642 & 2.645 \\
$\mathrm{BI}$ & -.209 & -.177 \\
$\mathrm{ABJ}$ & .007 & .016 \\
(Constant) & 2.532 & 2.581 \\
\hline
\end{tabular}

Tabel 11. Tabel Wilk's Lambda Klasifikasi Perdesaanperkotaan

Wilks' Lambda

\begin{tabular}{ccccc}
\hline $\begin{array}{c}\text { Test of } \\
\text { Function(s) }\end{array}$ & $\begin{array}{c}\text { Wilks' } \\
\text { Lambda }\end{array}$ & $\begin{array}{c}\text { Chi- } \\
\text { square }\end{array}$ & df & Sig. \\
\hline 1 & .952 & 3.731 & 1 & .053 \\
\hline
\end{tabular}

variabel independen (IR) dapat dijelaskan dari model diskriminan yang terbentuk. Nilai korelasi kanonikal menunjukkan hubungan antara nilai diskriminan dengan kelompok. Nilai kanonik sebesar 0,219 dan nilai p sebesar 0,05 memberikan makna bahwa, jika suatu wilayah diklasifikasikan menjadi perdesaan dan perkotaan maka terdapat hubungan antara variabel perdesaan-perkotaan dengan Incidence Rate Demam Berdarah Dengue.

Berdasarkan Tabel 10, model yang terbentuk untuk stratifikasi ekosistem pantai dan bukan pantai adalah sebagai berikut:

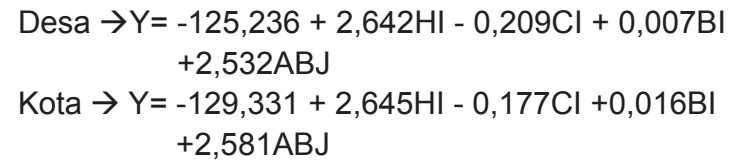

Berdasarkan Uji Wilk's Lambda di tabel 11, kedua model memiliki perbedaan yang signifikan, jika dilihat dari konstanta prediktor dan $p$-value, namun terdapat sebesar 5,3\% level kesalahan yang disebabkan oleh efek di luar penelitian. Dapat diambil kesimpulan bahwa dengan distratifikasi desa dan kota, terdapat hubungan antara indeks entomologi dengan Incidence Rate.

\section{Pembahasan}

Analisis diskriminan merupakan suatu teknik analisis multivariat yang digunakan untuk mengelompokkan atau mengklasifikasi suatu objek 
ke dalam dua kelompok atau lebih berdasarkan variabel terikatnya, dalam hal ini adalah Incidence Rate (IR) DBD di 78 Kabupaten di Indonesia. Asumsi utama dalam melakukan analisis diskriminan yaitu sejumlah $p$ variabel bebas harus berdistribusi normal dan matriks varian-kovarian variabel bebas berukuran pxp memiliki kesamaan/homogen. Uji Kolmogorov-Smirnov layak digunakan dalam penelitian ini karena uji Kolmogorov-Smirnov tidak dapat digunakan pada data dengan nilai rata-rata lebih kecil dari standar deviasi (Kuntoro, 2007). Berdasarkan Tabel 1, semua variabel baik variabel terikat dan variabel bebas memiliki rata-rata yang lebih besar dari nilai standar deviasinya. Variabel BI, ABJ dan $\mathrm{HI}$ memiliki nilai signifikan lebih dari 0,05 sehingga ketiga variabel tersebut sudah berdistribusi normal. Sedangkan 2 variabel yaitu $\mathrm{Cl}$ dan IR memiliki nilai signifikan kurang dari 0,05 karena belum berdistribusi normal.

Jika terdapat data yang tidak berdistribusi normal saat harus dilakukan analisis lanjut, ada beberapa metode yang harus dilakukan, yaitu: mentransformasi data ke dalam bentuk yang lain (remedies for non normal). Ada banyak cara mentransformasikan, tetapi cara yang sering dipakai adalah transformasi dalam bentuk akar kuadrat, arcsin, dan log10, jika mentransformasi data tidak bisa, menambah jumlah sampel penelitian, hingga lebih dari 100 sampel, membuang subjek yang teridentifikasi sebagai outliers dan langkah terakhir menggunakan statistik non parametrik (Apriyono \& Abdullah Taman, 2013). Data penelitian ini diketahui tidak berdistribusi normal pada variabel $\mathrm{Cl}$ dan IR, sehingga perlu dilakukan transformasi data. Sebelum dilakukan transformasi data, dilihat bentuk sebaran data. Tabel 3 merupakan tabel pedoman melakukan transformasi data berdasarkan bentuk grafik histogram. Jika grafik data sedikit condong ke kanan/arah positif, maka dilakukan transformasi SQRT(x), yaitu data diakar pangkat 2. Jika grafik data lebih condong ke kanan/arah positif, maka dilakukan transformasi $L G 10(x)$, yaitu data di logaritma pangkat 10 . Jika grafik data sangat condong ke kanan/arah positif, maka dilakukan transformasi $1 / x$. Jika grafik data sedikit condong ke kiri/arah negatif, maka dilakukan transformasi $S Q R T(k-x)$, dengan $\mathrm{k}$ adalah data dengan nilai paling tinggi. Jika grafik data lebih condong ke kiri/arah negatif, maka dilakukan transformasi $L G 10(k-x)$. Jika grafik data sangat condong ke kiri/arah positif, maka dilakukan transformasi $1 /(k-x)$.
Tabel 3 merupakan hasil uji normalitas data Kolmogorov-Smirnov untuk variabel $\mathrm{Cl}$ dan IR. Berdasarkan hasil transformasi data dan melakukan hasil uji normalitas, variabel IR sudah berdistribusi normal karena nilai signifikan lebih dari 0,05. Data $\mathrm{Cl}$ ditransformasi lagi menggunakan SQRT( nilai Max-x) karena Moderate negative skewness. Hasil uji Kolmogorov-Smirnov pada Tabel 4 menyatakan sebaran data sudah berdistribusi normal dengan nilai signifikansi sebesar 0,084. Dengan demikian semua variabel sudah berdistribusi normal.

Asumsi utama kedua analisis diskriminan yang harus dipenuhi adalah kesamaan varian-kovarian melalui uji Box's M. Uji ini digunakan untuk menguji apakah klasifikasi kategori pantai-bukan pantai dan perdesaan-perkotaan mempunyai varian yang sama diantara anggota kelompok tersebut. Pengujian kesamaan varians-kovarians dilakukan untuk menguji varians dari setiap variabel dengan menggunakan uji Box's M. Asumsi yang harus terpenuhi adalah group covariance matrices setiap variabel relatif sama (Rizkiana \& Hendikawati, 2015). Berdasarkan Tabel 5, nilai signifikan uji Box's M menunjukkan nilai homogenitas matriks kovarians 0,066, sehingga dapat disimpulkan bahwa varians/ragam kedua kelompok baik pantai-bukan pantai dan perdesaan-perkotaan memiliki kesamaan varian-kovarian. Berdasarkan uji asumsi utama analisis diskriminan yaitu uji kenormalan data dan uji kesamaan varian-kovarian data yang sudah memenuhi syarat untuk dilakukan analisis diskriminan.

Tabel 6 memberikan informasi hubungan variabel bebas berupa indeks entomologi dengan Incidence Rate (IR) Demam berdarah di 78 Kabupaten di Indonesia selama periode 2016-2017 berdasarkan klasifikasi pantai-bukan pantai. Nilai korelasi kanonik yang terdapat dalam tabel 6 dan tabel 8 berfungsi untuk mengetahui hubungan antar variabel dengan klasifikasi yang ditentukan serta mengevaluasi fungsi diskriminan yang terbentuk, untuk melihat kebaikan dari fungsi diskriminan, dapat dilihat pada nilai eigen dan nilai korelasi kanonik (Andriani et al., 2011). Nilai Canonical Correlation yang sangat rendah yaitu 0,076, menunjukkan tidak terdapat hubungan antara variabel bebas dengan variabel terikatnya jika diklasifikasikan ke dalam pantai-bukan pantai. Tabel 9 adalah tabel hasil analisis diskriminan untuk mengetahui apakah terdapat hubungan antara variabel bebas terhadap variabel terikatnya jika berdasarkan klasifikasi perdesaan-perkotaan. 
Berdasarkan Tabel 9, nilai Canonical Correlation yang cukup tinggi yaitu 0,219 , sehingga dapat disimpulkan bahwa fungsi diskriminan yang terbentuk lebih baik jika dibandingkan fungsi diskriminan dari pengklasifikasian berdasarkan pantai-bukan pantai serta terdapat hubungan antara variabel bebas dengan variabel terikatnya jika diklasifikasikan ke dalam perdesaan-perkotaan.

Dalam penelitian ini, kasus demam berdarah dengue dilihat berdasarkan nilai Incidence Rate (IR) di 78 kabupaten di Indonesia. Demam berdarah dengue banyak terjadi di daerah perkotaan yang padat penduduk. Perbedaan habitat kedua jenis genus Aedes merupakan salah satu mekanisme untuk mempertahankan koeksistensi geografis (Thavara et al., 2004). Ae. aegypti lebih menyukai daerah perkotaan dan domestik, yaitu di sekitar tempat tinggal manusia dan cenderung berkembang biak di kontener buatan (Kementerian Kesehatan Republik Indonesia, 2017), sedangkan Ae. albopictus banyak ditemukan pada daerah pedesaan dan lebih banyak berkembang di habitat alami (Rey and O'Connell, 2014), tetapi ditemukan pula pada tempat penampungan air di rumah penduduk (Dieng et al., 2010). Berdasarkan Tabel 6 dan Tabel 9 hasil analisis diskriminan, kasus demam berdarah dengue di Indonesia berkaitan dengan persebaran nyamuk di wilayah perdesaan-perkotaan daripada di wilayah pantai-bukan pantai. Nyamuk vektor demam berdarah dengue lebih banyak ditemukan di pemukiman yang padat penduduk. Pola spasial antara penggunaan lahan dengan sebaran kejadian DBD, menunjukkan bahwa kejadian DBD berada pada wilayah permukiman yang berdekatan dengan aliran sungai, persawahan dan jalan lokal yang cenderung terjadi mobilitas penduduk yang cukup tinggi. Berdasarkan Thomas et al. (Thomas et al., 2009) penggunaan lahan adalah usaha manusia memanfaatkan lingkungan alamnya untuk memenuhi kebutuhan tertentu dalam kehidupan dan keberhasilannya yang berdampak pada perubahan pemanfaatan lahan dari suatu fungsi ke fungsi lainnya untuk kegiatan tertentu. Banyak penelitian telah difokuskan pada faktor penggunaan lahan dan tingginya jumlah vektor dengue di daerah kecil tapi belum mempelajari hubungan antara faktor-faktor penggunaan lahan dan kasus demam berdarah dengue untuk daerah besar. Penelitian Cheong et al. (Cheong et al., 2014) bertujuan untuk menjelaskan jika penggunaan lahan selain faktor pemukiman manusia, misalnya berbagai jenis penggunaan lahan pertanian, bendungan air dan hutan juga terkait dengan kasus demam berdarah dengue dilaporkan 2008-2010 di negara bagian Selangor, Malaysia. Dari studi korelatif menghasilkan peta risiko prediksi, hasil menunjukkan bahwa faktor penggunaan lahan yang paling berpengaruh adalah pemukiman manusia $(39,2 \%)$, diikuti oleh badan air $(16,1 \%)$, hortikultura campuran $(8,7 \%)$, lahan terbuka $(7,5 \%)$ dan padang rumput $(6,7 \%)$. tempat berkembangnya nyamuk Ae. aegypti adalah pada daerah dataran rendah tidak pada daerah pantai (Indrayati \& Setyaningsih, 2013). Kepadatan penduduk tinggi akan mempengaruhi jumlah sebaran kasus DBD karena penyebaran penyakit demam berdarah yang ditularkan nyamuk Ae. aegypti didukung jumlah penduduk yang padat di daerah endemik. Kepadatan pemukiman tinggi akan mempengaruhi jumlah sebaran kasus DBD karena penyebaran penyakit demam berdarah yang ditularkan nyamuk $A$ e. aegypti didukung padat pemukim di daerah endemik sehingga memudahkan penularan DBD dari rumah ke rumah.

Banyaknya kebun bambu dan pepohonan rindang, sangat mendukung untuk tempat perindukan nyamuk. Ditambah dengan kepadatan permukiman memudahkan penyebarluasan dan penularan penyakit seperti DBD. Sehingga semakin dekat jarak satu rumah dengan rumah lainnya, semakin mudah nyamuk untuk menyebar ke rumah lainnya (Nisaa et al., 2016). Didaerah permukiman yang dekat dengan pantai pun terdapat kasus DBD, tetapi sebarannya tidak seperti pada permukiman padat penduduk. Hasil survei jentik, bahwa kemungkinan terjadi penularan di tempat dimana penderita beraktivitas maupun di rumah dan sekitar rumah penderita. Kondisi air tanah di wilayah dekat pantai sudah tercemar oleh material minyak dan air laut, sehingga air tanah tidak lagi layak digunakan lagi oleh masyarakat. Ketersediaan air bersih pada masyarakat pesisir pantai sangat bergantung pada air hujan. Air hujan yang ditampung pada drum yang tidak tertutup dapat berpotensi sebagai breeding place vektor nyamuk (Handoyo et al., 2015).

\section{Kesimpulan}

Berdasarkan analisis dari nilai Eigen, klasifikasi pantai-bukan pantai tidak memiliki pengaruh terhadap hubungan indeks entomologi dengan incidence rate sedangkan klasifikasi perdesaan-perkotaan berpengaruh nyata terhadap hubungan indeks entomologi terhadap incidence rate. Dapat disimpulkan bahwa lingkungan yang 
padat penduduk seperti di perkotaan dan perdesaan sangat berpeluang terhadap terjadinya kasus demam berdarah dengue di daerah endemis DBD.

\section{Saran}

Berdasarkan kesimpulan yang dihasilkan, analisis diskriminan Fisher's dapat dijadikan sebagai metode matematis untuk menentukan klasifikasi mana yang lebih tepat untuk digunakan. Penelitian ini diharapkan dapat menjadi salah satu pustaka untuk pengambil kebijakan dalam pengendalian demam berdarah dengue di daerah endemis DBD. Perlu monitoring secara berkala terhadap keberadaan jentik nyamuk di ekosistem perdesaan dan perkotaan. Peningkatan kesadaran individu melalui sosialisasi program pencegahan dan pengendalian penyakit demam berdarah dengue sangat diperlukan terutama di masyarakat yang bertempat tinggal di pemukiman padat penduduk yang memiliki masalah sangat kompleks tentang sanitasi lingkungan. Diharapkan masyarakat lebih peduli terhadap lingkungan, menjaga kebersihan baik di dalam rumah maupun di luar rumah, tidak membiarkan adanya genangan air di tempat penampungan air.

\section{UCAPAN TERIMA KASIH}

Ucapan terima kasih kami sampaikan kepada Kepala Badan Penelitian dan Pengembangan Kesehatan yang telah memberikan dukungan penuh kegiatan Riset Khusus Vektor dan Reservoir Penyakit beserta Kepala Balai Besar Penelitian dan Pengembangan Vektor dan Reservoir Penyakit Salatiga dan Ketua Panitia Pembina IImiah B2P2VRP (Dra. Widiarti, M.Kes) yang telah membina dalam penulisan artikel, memberi masukan dan saran demi terselesaikannya artikel ini. Kami sampaikan terima kasih kepada Ketua Laboratorium (Dr. Dwi Hapsari Tjandrarini) dan teman-teman di Laboratorium Manajemen Data yang telah memberikan semangat dan dorongan untuk selalu konsisten menulis karya tulis ilmiah.

\section{DAFTAR PUSTAKA}

Andriani Y, Cahyawati D \& Gusmaryanita V, 2011. Analisis Diskriminan untuk Mengetahui Faktor yang Mempengaruhi Pilihan Program Studi Matematika di FMIPA dan FKIP Universitas Sriwijaya. Jurnal Penelitian Sains, 14(4(A)), pp.9-14.
Apriyono A \& Abdullah Taman, 2013. Analisis Overreaction Pada Saham Perusahaan Manufaktur Di Bursa Efek Indonesia (Bei) Periode 2005-2009. Jurnal Nomina, 2(2), pp.76-96.

Astuti EP, Fuadzy H \& Prasetyowati H, 2016. Pengaruh Kesehatan Lingkungan Pemukiman Terhadap Kejadian Demam Berdarah Dengue Berdasarkan Model Generalized Poisson Regression Di Jawa Barat (Analisis Lanjut Riskesdas Tahun 2013). Buletin Penelitian Sistem Kesehatan, 19(1), pp.109-117.

Burattini M, Chen M, Chow A, Coutinho F, Goh K, Lopez L, et al., 2007. Modelling the Control Strategies Against Dengue in Singapore. Epidemiology and Infection., 136(1), p.309-319.

Centers for Disease Control and Prevention, 2012. Dengue and Climate. Available at: www.cdc.gov/dengue.

Cheong Y, Leitao P \& T L, 2014. Assessment of Land Use Factors Associated With Dengue Cases in Malaysia Using Boosted Regression Trees. Spat Spatiotemporal Epidemiol., 5(2).

Craven RB, Eliason DA \& D.B.Francy, 2008. Importation of Aedes albopictus and other exotic species into the United States in used tires from Asia. Journal America Mosquitoes Controll Association., 4(1), pp.138-42.

Dahlan MS, 2009. Statistik untuk Kedokteran dan Kesehatan, Edisi 4 (Deskriptif, Bivariat dan Multivariat, dilengkapi Aplikasi dengan Menggunakan SPSS)., Jakarta: Salemba Medika.

Dieng H, Saifur R, Hassan A, Salmah M, Boots M \& Satho $\mathrm{T}, 2010$. Indoor-Breeding of Aedes Albopictus in Northern Penin-sular Malaysia and its Potential Epidemiological Implications. PLoS One, 5(7), p.e11790.

Dini AMV, Rina N \& R.A. Wulandari, 2010. Faktor Iklim dan Angka Insiden Demam Berdarah Dengue di Kabupaten Serang. Makara Kesehatan, 14(1), pp.31-8.

Fidayanto R, Susanto H, Yohanan A \& Yudhastut R, 2013. Model Pengendalian Demam Berdarah Dengue. Jurnal Kesehatan Masyarakat Nasional, 7(522-8).

Focks D, Alexander N \& Villegas E, 2007. Multicountry Study of Aedes aegypti Pupal Productivity Survey Methodology: Findings and Recommendations. Dengue bulletin WHO, 31(1), pp.192-200.

Handoyo W, Hestiningsih R \& Martini, 2015. Hubungan Sosiodemografi Dan Lingkungan Fisik Dengan Kejadian Demam Berdarah Degue (DBD) Pada Masyarakat Pesisir Pantai Kota Tarakan (Studi Kasus Pada Daerah Buffer Kantor Kesehatan Pelabuhan Kelas II Tarakan). JURNAL KESEHATAN MASYARAKAT (e-Journal), 3(3), pp.186-195.

Honório NA, Cabello PH, Codeço CT \& Lourenço-de-Oliveira $R, 2006$. Preliminary Data on the Performance of Aedes aegypti and Aedes albopictus Immatures Developing in Water-filled Tires in Rio de Janeiro. Mem Inst Oswaldo Cruz, 101(1), pp.225-28. 
Indrayati A \& Setyaningsih W, 2013. Penentuan Lokasi Prioritas Penanganan Kasus Demam Berdarah Di Kota Semarang Berbasis Sistem Informasi Geografis. Jurnal Forum IImu Sosial, 40(1), pp.56-67.

Johnson RA \& Wichern DW, 2007. Applied Multivariate Statistical Analysis. Sixth Edition. Sixth Edit., New Jersey: Prentice Hall International. Inc.

Juliano SA, Lounibos LP \& G.F. O'Meara, 2004. A Field Test for Competitive Effects of Aedes albopictus on A. aegypti in South Florida: Differences between Sites of Coexistence and Exclusion? Oecologia, 139(2), pp.583-93.

Kementerian Kesehatan Republik Indonesia, 2017. Data dan Informasi Profil Kesehatan Indonesia Tahun 2017 1st ed. M. S. drg. Rudy Kurniawan, M. Kes Boga Hardhana, S.Si, MM Yudianto, SKM, ed., Jakarta: Pusat Data dan informasi Kementerian Kesehatan Republik Indonesia.

Kementerian Kesehatan RI., 2017. Kemenkes Optimalkan PSN Cegah DBD. www.depkes.go.id, pp.1-2. Available at: http://www.depkes.go.id/pdf.php?id=17061500001 [Accessed December 11, 2018].

Khairunisa Ummi; Nur Endah Wahyuningsih dan Hapsari, 2017. Kepadatan Jentik Nyamuk Aedes sp. (House Index) sebagai Indikator Surveilans Vektor Demam Berdarah Dengue di Kota Semarang. JURNAL KESEHATAN MASYARAKAT (e-Journal), 5(5), pp.906-910. Available at: http://ejournal3.undip. ac.id/index.php/jkm.

Khin MM \& Than KA, 2003. Transovarial transmission of dengue-2 virus by Aedes aegypti nature. American Journal and Tropical Medicine and Hygiene, 32(1), pp.590-4.

Kuntoro, 2007. Metode statistik, Surabaya: Putaka melati.

Lei HY, Yeh TM, Liu HS, Lin YS, Chen SH \& Liu CC, 2001. Immunopathogenesis of Dengue Virus Infection. $J$ Biomed Sci., 8(1), p.377-88.

Mulyati SA, Ruslan Majid \& Ibrahim K, 2017. Studi Spasial Persebaran Penyakit Demam Berdarah Dengue (DBD) Di Wilayah Kerja Puskesmas Lepo-Lepo Kota Kendari Tahun 2013-2016. Universitas Halu Oleo.

Nakhapakorn K \& N.K. Tripathi, 2005. An Information Value Based Analysis of Physical and Climatic Factors Affecting Dengue Fever and Dengue Haemorrhagic Fever Incidence. International Journal of Health Geographisc., 4(13).

Nisaa A, Hartono \& Sugiharto E, 2016. Analisis Spasial Dinamika Lingkungan Pada Kejadian DBD Berbasis GIS di Kecamatan Colomadu Kabupaten Karanganyar. Journal of Information Systems for Public Health, 1(2), pp.23-8.
Oktaviani MA \& Notobroto HB, 2014. Perbandingan Tingkat Konsistensi Normalitas Distribusi Metode KolmogorovSmirnov, Lilliefors, Shapiro-Wilk, dan SkewnessKurtosis. Jurnal Biometrika dan Kependudukan, 3(2), pp.127-135.

Passos RA, Marques GRA., J.C.Voltolini \& M.L.F. Condino, 2003. Dominance of Aedes aegypti over Aedes albopictus in the Southeastern Coast of Brazil. Rev Saude Publica, 37(1), pp.729-34.

Pham HV, Doan HTM, Phan TTT \& N.N.T. Mint, 2011. Ecological Factors Associated with Dengue Fever in a Central Highlands Province, Vietnam. BMC Infectious Diseases., 11(172), pp.1-6.

Prabawa KA, Suciptawati NLP \& Nilakusmawati DPE, 2017. Penerapan Analisis Korelasi Kanonik Pada Hubungan Kualitas Pelayanan Terhadap Kepuasan Nasabah. E-Jurnal Matematika, 6(1), pp.90-8.

Promprou S, 2005. Impact of Climatic Factors on Dengue Haemorrhagic Fever Incidence in Southern Thailand. Walailak J Sci \& Tech., 2(1).

Rey J \& O'Connell S, 2014. Oviposition by Aedes aegypti and Aedes albopictus: Influence of Congeners and of Oviposition Site Characteristics. J. of Vec. Ecol., 39(1), pp.190-6.

Rizkiana A \& Hendikawati P, 2015. Klasifikasi Tingkat Kepuasan Pelanggan Dengan Analisis Diskriminan. Jurnal MIPA, 38(1), pp.89-100.

Rofiq A, Wuryandari T \& Rahmawati R, 2016. Perbandingan Analisis Diskriminan Fisher Dan Naive Bayes Untuk Klasifikasi Risiko Kredit (Studi Kasus Debitur Di Koperasi Jateng Amanah Mandiri Cabang Sukorejo Kendal). Jurnal Gaussian, Volume 5(1), pp.1-10.

Rosy T, 2018. ANALISISDISKRIMINAN. daps.bps.go.id/ file_artikel/65/, pp.1-10.

Sulistyorini Evi, Hadi UK \& Soviana S, 2016. Faktor Entomologi Terhadap Keberadaan Jentik Aedes sp. Pada Kasus DBDTertinggi Dan Terendah Di Kota Bogor. JURNAL MKMI, 12(3), pp.134-47.

Thavara U, Tawatsin A \& Chompoosri J, 2004. Evaluation of Attractants and Egg-lying Substrate Preference for Oviposition by Aedes albopictus (Diptera : Culicidae). $J$ of Vec. Ecol., 29(1), p.66 - 72.

Thomas W, Hertel, Steven K \& Rose R, 2009. Economic Analysis of Land Use in Global Climate Change Policy. I., New York: Routledge Inc.

Yap BW \& Sim CH, 2011. Comparisons of various types of normality tests,. Journal of Statistical Computation and Simulation, 81(12), pp.2141-55. 